Primljen/Received: 16.11.2016. Ispravljen/Corrected: 22.5.2017.

Prihvaćen/Accepted: 28.6.2017.

Dostupno online/Available online: 10.10.2017.

\section{Influence of early-age concrete behaviour on concrete pavements performance}

Authors:

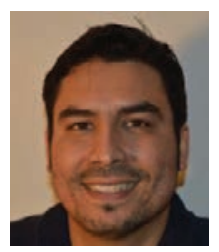

Assist.Prof. Mauricio Pradena, PhD.CE. University of Concepción, Čile Faculty of Civil Engineering mpradena@udec.cl

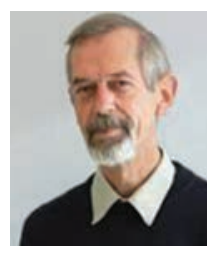

Assoc.Prof. Lambert Houben, PhD. CE Delft University of Technology Section Pavement Engineering L.J.M.Houben@tudelft.nl

\section{Mauricio Pradena, Lambert Houben}

Subject review

\section{Influence of early-age concrete behaviour on concrete pavements performance}

Cracks in joints are the consequence of concrete behaviour in the initial period of use of pavement structures, which can affect structural properties of concrete pavements. Current knowledge on the influence of concrete in the initial period of use of concrete pavement structures is analysed in the paper. The analysis has shown that interaction (in space and time) of the group of joints must be taken into account in the scope of crack behaviour modelling. As a result of this approach, the relationship between joints and crack width can be predicted in order to evaluate their effects on properties of concrete pavements.

Key words:

concrete pavement, early-age concrete, cracks, joints, structural properties, load transfer

Pregledni rad

Mauricio Pradena, Lambert Houben

\section{Utjecaj ponašanja svježeg betona na svojstva betonskih kolnika}

Pukotine u razdjelnicama posljedica su ponašanja betona u početku uporabe konstrukcije što može utjecati na konstrukcijska svojstva betonskih kolnika. U radu se analiziraju dosadašnja znanja za procjenu utjecaja betona u početnom periodu uporabe betonske kolničke konstrukcije. Ispitivanje je pokazalo da je pri modeliranju ponašanja pukotina potrebno uzeti u obzir međudjelovanje (u vremenu i prostoru) grupe razdjelnica. Kao rezultat takvog pristupa može se predvidjeti odnos razdjelnica i širina pukotina kako bi se procijenili njihovi učinci na svojstva betonskih kolnika.

Ključne riječi:

betonski kolnik, svježi beton, pukotine, razdjelnice, konstrukcijska svojstva, prijenos opterećenja

Übersichtsarbeit

Mauricio Pradena, Lambert Houben

\section{Auswirkung von Frischbeton auf die Eigenschaften von Betonfahrbahnen}

Risse in den Trennfugen ergeben sich aus dem Verhalten des Betons am Beginn des Einsatzes einer Konstruktion, was sich auf die Konstruktionseigenschaften von Betonfahrbahnen auswirken kann. In der Arbeit werden die bisherigen Kenntnisse in Bezug auf die Beurteilung der Auswirkung von Beton am Beginn der Nutzung einer Betonfahrbahn ausgewertet. Die Untersuchung hat ergeben, dass bei der Modellierung des Rissverhaltens die Interaktion (zwischen Zeit und Raum) von Trennfugengruppen zu berücksichtigen ist. Infolge eines solchen Ansatzes können das Verhältnis zwischen den Trennfugen und der Rissbreite vorgesehen und die Auswirkungen auf die Eigenschaften von Betonfahrbahnen beurteilt werden.

Schlüsselwörter:

Betonfahrbahn, Frischbeton, Risse, Trennfugen, Konstruktionseigenschaften, Lastübertragung 


\section{Introduction}

The characteristics of concrete as paving material make it particularly valuable in critical traffic hubs such as at intersections or roundabouts, bus corridors, bus stops, bus stations, (interurban and urban) highways with predominant truck traffic, airport aprons, industrial yards, and floors. In particular, in Jointed Plain Concrete Pavements (JPCPs) cracks are produced under the joints as a result of early-age restricted deformations in concrete. The magnitude of these crack widths can have a positive or negative effect on the JPCP in-service performance, especially in the case of non-dowelled pavements where aggregate interlock is the most influential load transfer mechanism [1-3]. Nowadays there are not only non-dowelled traditional JPCPs (slab length $\geq 3.5 \mathrm{~m}$ ) but also JPCPs with short slabs (slab length $<2.5 \mathrm{~m}$ ), which is an innovation that does not include dowel bars in their design features.

Short-slab JPCPs imply a change of paradigm regarding traditional practice of limiting the number of joints. The reduction of joint spacing produces a new traffic load configuration for the slabs, as well as a reduction of slab curvature that allows the slabs to resist a greater traffic load compared to traditional JPCPs of the same thickness [4], while enabling JPCPs of reduced thickness to resist the same traffic demand [5]. The savings can reach up to $30 \%$ since their joints are also unsealed [5-6]. Several practical experiences have pointed to good behaviour of this innovation [5-6]. For instance, Roesler et al. [4] performed an Accelerated Pavement Testing (APT) at three $40 \mathrm{~m}$ test sections of short concrete slabs $1.8 \mathrm{~m}$ in length at the University of Illinois (USA). Some aspects of the short-slab technology have been patented by a private Chilean company [7-9]. This situation and the continued interest for applied research and pavement innovations of the National Highway Laboratory (NHL) of Chile have resulted in a concentration of test sections and projects involving short slabs in Chile.

The objective of this paper is to analyse the knowledge available to evaluate the effects of the early-age concrete behaviour on structural performance of JPCPs. In this respect, current possibilities of modelling the early-age concrete behaviour in JPCPs are analysed. Afterwards, the state of the art regarding the effects of Uncracked Joints (UnCrJ) and crack width (at joints) on structural performance of JPCPs is analysed. Although the analysis presented in this paper is valid for JPCPs in general, a special attention is paid to short slabs not only because it is a pavement innovation, but also because it is (explicitly) a nondowelled JPCP where the load transfer is provided by aggregate interlock, i.e. it depends directly on the crack width (at joints) resulting from the early-age concrete behaviour.

\section{Modelling cracking process of JPCPs}

More than models to predict the cracking process of JPCPs, what it is available in the state of the art are formulas to calculate part of the cracking process, in general the joint opening. The classic formula of the American Association of State Highway and Transportation Officials (AASHTO) [10] is used to calculate the joint opening $\Delta L(\mathrm{~mm})$, caused by temperature change and drying shrinkage as a function of the slab length $L(\mathrm{~mm})$.

$\Delta L=C \cdot L \cdot\left(\alpha_{t} \cdot \Delta T+\varepsilon\right)$

where, $\Delta L$ is influenced by the Coefficient of Thermal Expansion (CTE) $\alpha_{t}\left({ }^{\circ} \mathrm{C}^{-1}\right)$; the temperature range $\Delta \mathrm{T}\left({ }^{\circ} \mathrm{C}\right)$; the drying shrinkage coefficient $\varepsilon(\mathrm{mm} / \mathrm{mm})$ and the slab-base friction C (-). Later, the Mechanistic-Empirical Pavement Design Guide (MEPDG) used a refined version of the AASHTO formula for the prediction of the joint width jw (in), caused by temperature change and shrinkage, and expressed as a function of the slab length JTSpace (ft) [11].

$j w=\operatorname{Max}\left(12000 \cdot J T S p a c e \cdot \beta \cdot\left(\alpha_{P C C} \cdot\left(T_{\text {constr }}-T_{\text {mean }}\right)+\varepsilon_{\text {sh,mean }}\right), 0\right)$

where, the CTE is $\alpha_{P C C}\left(\mathrm{in} / \mathrm{in} /{ }^{\circ} \mathrm{F}\right)$; the concrete temperature at set $T_{\text {constr }}\left({ }^{\circ} \mathrm{F}\right)$; the mean monthly night-time temperature $T_{\text {mean }}\left({ }^{\circ} \mathrm{F}\right)$, the mean shrinkage strain $\varepsilon_{\text {sh,mean }}$ (in/in) and the joint open/close coefficient $\beta$ (-), similar to the coefficient C in Eq. 1.

An equation to predict the crack width under the joints of JPCPs was developed as a part of improvements of the South African design method for concrete pavements [12]:

$\Delta x=\left[\begin{array}{l}\left.\frac{C_{3}}{h} \cdot\left\{\alpha_{1} \cdot \alpha_{2} \cdot \alpha_{3} \cdot\left(0.019 \cdot \frac{w^{2.1}}{f^{0.28}}+270\right)+(900-t) \cdot(t-0.08)^{0.18}\right\}\right] \cdot L(3) \\ \cdot\left(1-h_{u}\right)+\left(T_{0}-T_{t}\right) \cdot \eta\end{array}\right.$

where:

$\mathrm{C}_{3}$ - Constant

h - Slab thickness [m]

$\alpha_{1}$ - Coefficient of cement type

$\alpha_{2}$ - Factor of curing

$\alpha_{3}$ - Factor of aggregate type

w - Water content of concrete [MPa]

$h_{u}$ - Factor of relative humidity

$F$ - Cylinder compressive strength of concrete

t - Time (years)

$\mathrm{T}_{0}$ - Temperature at time of paving $\left[{ }^{\circ} \mathrm{C}\right]$

$T_{t}$ - Present temperature $\left[{ }^{\circ} \mathrm{C}\right]$

$\eta$ - Thermal coefficient of concrete $\left[{ }^{\circ} \mathrm{C}^{-1}\right]$

L - Slab length [m].

Searching for a refinement of the AASHTO model [10], Roesler \& Wang [13] developed an algorithm for the prediction of the joint opening. For that, they modified the analytical model developed by Zhang \& Li [14] in which, originally, only the drying shrinkage effect was considered. Roesler \& Wang [13] modified the model in order to incorporate the temperature changes as well. 
The described models have at least two characteristics in common:

- They do not consider the viscoelastic behaviour of the concrete since earlyage

- They ignore the interaction (in time and space) and the effects of the behaviour of the group of slabs in the prediction of a particular joint opening.

Beom \& Lee [15] state that a cracked joint adjacent to UnCrJ would show an erratic large joint opening. This conclusion is based on investigations made on JPCPs

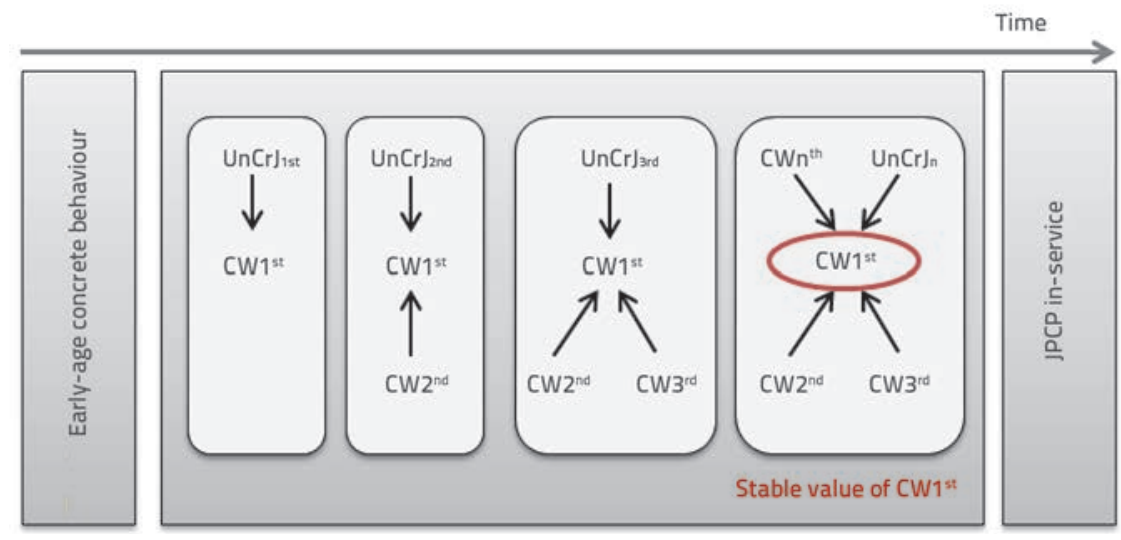

Figure 2. Effects of UnCrJ and CW of different series of cracks on CW value of the $1^{\text {st }}$ series of cracks [22] (JPCP - Jointed Plain Concrete Pavements) in the USA and Korea, and previous investigations related to the design and performance of joint seals [16-18]. These studies confirm the earlier conclusions of Morian et al. [19] based on in situ investigations on JPCPs in the USA, in the sense that the AASHTO method is not able to adequately represent the joint opening observed in the field. In effect, all the mentioned investigations applied this formula, and all the studies conclude that this approach cannot predict the joint opening adequately. But the problem is not exclusively related to the AASHTO formula, because the main cause of the larger joint openings observed in the field is the omission of the effects of the $\mathrm{UnCr}$ ] in the determination of the joint opening under study.

UnCr] is not uncommon in JPCPs. Besides the referenced studies, the presence of $\mathrm{UnCr}$ ] in real-world JPCPs has been reported by other authors such as Zollinger et al. [20] and Pradena \& Houben [21]. In particular, Pradena \& Houben [21] identified in the field the presence of UnCrJ even when traditional technical specifications for the saw-cutting depth were fulfilled.

a)

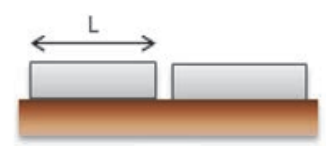

b)

$2 \mathrm{~L}$

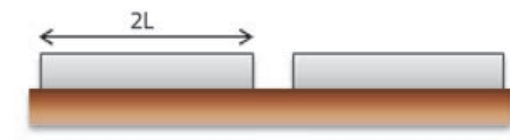

c)

3L

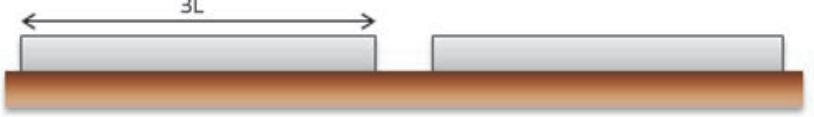

Figure 1. Representation of JPCP system effects on a particular joint opening [22]

Figure 1 is a representation of the effects on the opening of a particular joint as a function of behaviour of the adjacent joints. Figure 1.a shows the joint opening when all the joints are activated. In this case, the effective slab length is equal to the designed slab length (L). A larger joint opening should be expected when the adjacent joints are not activated (Figure 1.b). In this case the effective slab length is the double of the designed slab length, i.e. 2L. An even larger joint opening should be expected when four adjacent joints (two at each side) are not activated (Figure 1.c). In this case, the effective slab length is three times greater compared to the originally designed slab length, i.e $3 \mathrm{~L}$.

Morian and Stoffels [23] and Morian et al. [19] suggest that the in-situ interaction between joints, causing larger joint openings than the calculated ones, represents a reasonable explanation of the failure of joint seals. In the particular case of short slabs, Roesler et al. [4] suggest an interaction between the joints with the development of the cracking pattern of the JPCP. According to Roesler et al. [4], this interaction in time affects the Load Transfer Efficiency (LTE) of the non-dowelled short slabs. However this suggested interaction was not studied considering the relationship LTE - crack width, i.e. with the most influential load transfer mechanism in non-dowelled JPCPs, the aggregate interlock [1-3].

Figure 2 shows the effect of development in time of the JPCP cracking pattern over the crack width value under study, in this case the Crack Width of the $1^{\text {st }}$ series of cracks ( $\mathrm{CW} 1^{\text {st }}$ ), i.e. the joints that are first activated. It can be observed in Figure 2 that not only the development in time of the UnCrJ has an effect on the $\mathrm{CW} 1^{\text {st }}$, but also the development of the cracking pattern, i.e. the Crack Width of the $2^{\text {nd }}$ series of cracks (CW2 ${ }^{\text {nd }}$ ), the Crack Width of the $3^{\text {rd }}$ series of cracks $\left(C W 3^{\text {rd }}\right)$, and so on. After the cracking pattern is completed (Crack Width of the ' $n$ th' series of cracks, $\left(W^{\text {th }}\right)$, a process that can take several months, a stable value of the CW1 ${ }^{\text {st }}$ develops, which is the one that is useful for the link with the in-service JPCP.

The investigations of Beom \& Lee [15], Lee \& Stoffels [16], Lee \& Stoffels [17], Lee [18], and Morian et al. [19] focussed on the analysis of joint seals of in-service JPCPs. In fact, the procedure developed by Lee \& Stoffels [16] is not applicable to new JPCPs. Moreover, Lee \& Stoffels [17] explicitly acknowledge the necessity of having a model to predict the $\mathrm{UnCrJ}$ phenomenon and the progress of the transverse cracking since early-age in JPCPs. 


\section{Effects of early-age concrete behaviour on structural performance of JPCPs}

One of the largest groups of pavement clients are the agents acting on behalf of the owners, for instance the highway agencies, departments of transportation, and municipal transportation agencies. These agencies assign priority to structural adequacy of pavements [24]. In order to contribute to these pavement clients' satisfaction, the analyses in this article are concentrated on practical and useful methods to be used by the agencies. Hence, although Finite Elements (FE) are an important tool for structural pavement analysis, in general they cannot easily be implemented as part of a practical design method as the Mechanistic-Empirical (M-E) ones. Therefore, the analysis of the state of the art presented in this section is focussed in M-E pavement design methods.

In addition, from what was presented in the previous section, the relevant results of the early-age concrete behaviour that can affect the in-service structural performance of JPCPs, are the crack width (at joints) and the UnCrJ in JPCPs.

\subsection{Crack width (at joints)}

As stated before, crack width is directly related to the LTE of the in-service JPCPs. This influence is even more evident in non-dowelled JPCPs where the LTE depends on aggregate interlock. Hence, it is necessary to study the way in which the $\mathrm{M}-\mathrm{E}$ methods include the LTE for the design of JPCPS.

The Westergaard equation for slab edge stress due to an equivalent tire load includes different limiting assumptions that differ from real-world concrete slabs. In order to address these limitations, loannides [25] outlined a methodology based on the application of the principles of dimensional analysis. This methodology has been incorporated into different M-E design procedures [26-34].

In particular, to overcome the Westergard assumption of an isolated slab and to include the LTE, loannides et al. [35], loannides \& Korovesis [36], Salsilli [29], loannides et al. [37], and Cabrera [38], use the Eq. (4) as an adjustment factor.

$$
\begin{aligned}
F_{L T E} & =0.996573+0.00439187 \cdot L T E-0.00005851 \cdot(L T E)^{2} \\
& -0.003124 \cdot\left(\frac{a}{l}\right) \cdot L T E-0.03682 \cdot \ln (L T E)
\end{aligned}
$$

where:

a - radius of circular tire contact area [mm]

I - radius of relative stiffness of concrete slab [mm].

Other M-E methods for the design of traditional JPCPs do not necessarily use Eq. (4) but they also include the LTE to adjust their calculations to the reality of the load transfer between slabs in JPCPs. Examples of such methods can be found in the Netherlands [39], Sweden [40], USA [41], Chile [42], etc.. However, these methods or the ones using Eq. (4) do not include a direct relation with the most influential load transfer mechanism in non-dowelled JPCPs, i.e. the aggregate interlock (and then the crack width under the joints product of the early-age concrete behaviour). The exceptions are the MEPDG [11] and the South African design method for concrete pavements [12]. However, both methods do not consider viscoelastic behaviour of concrete since early-age in the development of the cracking process. Furthermore, they do not explicitly include the interaction (in time and space) and the effects of the behaviour of the group of joints in prediction of crack width to be related with the LTE.

In the particular case of short JPCP slabs, Salsilli et al. [34,43] developed a practical M-E design method using dimensional analysis [25]. Salsilli et al. [34, 43] adapted the adjustment factor for load transfer originally developed for traditional JPCPs (Eq. 4) to make it applicable to short JPCP slabs. In addition, the Chilean Highway Agency [42] developed a method for structural design of short slabs. In this method, LTE values are recommended to adjust the calculations [42]. However, although the investigations of short slabs have been focussed on structural analysis of this non-dowelled JPCP [4-6, 34, 42-45], they do not include a direct relation with the most influential load transfer mechanism in non-dowelled JPCPs, i.e. the aggregate interlock (and then the crack width under the joints product of the earlyage concrete behaviour). The approach of Covarrubias $[5,6]$ is similar to that of MEPDG, i.e. it does not consider viscoelastic behaviour of the early-age concrete or the interaction (in time and space) and the effects of the behaviour of the group of joints in the prediction of crack width to be related with the LTE. For short concrete slabs, Salsilli et al. [34] acknowledge the necessity to make specific studies of the LTE in this innovation. Although Roesler et al. [4] performed measurements of LTE in non-dowelled short slabs, they did not study the LTE - crack width relationship.

\subsection{Uncracked joints}

As mentioned before, previous researchers have studied the UnCrJ phenomenon [15-18]. However, these investigations have been focused on the design and performance of joint seals rather than on the effects of the $\mathrm{UnCrJ}$ on structural performance of JPCPs.

The UnCrJ not only affects the crack width and through that the LTE, but it also determines the effective slab length of the in-service JPCP. This effective slab length will be different from the designed slab length in the structural JPCP design, if $\mathrm{UnCrJ}$ are present. The presence of $\mathrm{UnCr}$ J is particularly relevant for short JPCP slabs because the postulated benefits of this innovation are valid only if the slabs are effectively shorter. One consequence of the presence of $\mathrm{UnCr}$ J is the larger width of cracks in the activated joints. Figure 3a presents the case of $0 \%$ $\mathrm{UnCr}$, i.e. the effective slab length is the same as the designed slab length ( $2 \mathrm{~m}$ in the example). On the contrary, only $50 \%$ of the joints are activated in Figure 3b. In this case, the effective 
slab length is twice the designed slab length ( $4 \mathrm{~m}$ in the example).

Figure 4 shows variations of the LTE with the crack width, in particular the LTE associated to the crack width of $1.0 \mathrm{~mm}(70 \%)$ and $2.0 \mathrm{~mm}(39 \%)$. The calculations were made with the $3 \mathrm{D}$ FE program EverFE [46] considering short slabs JPCPs of $2 \mathrm{~m}$ (by $2 \mathrm{~m}$ ) of an industrial floor (120 $\mathrm{mm}$ in thickness) when the front axle of a Forklift Toyota 7FBMF25 (www.toyota-forklifts.eu) is
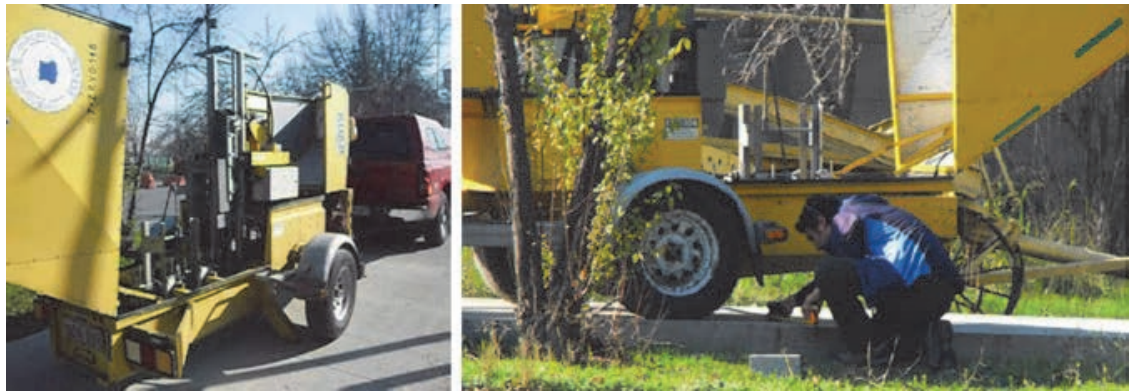

Figure 5. Application of repeated load with FWD on uncracked joint [22] positioned just before the joint. Concrete properties of the slabs are as follows: elastic modulus $29000 \mathrm{MPa}$, Poisson's ratio 0.2, CTE 1.1E-5 oC-1, and concrete density $2400 \mathrm{~kg} / \mathrm{m}^{3}$.

a)
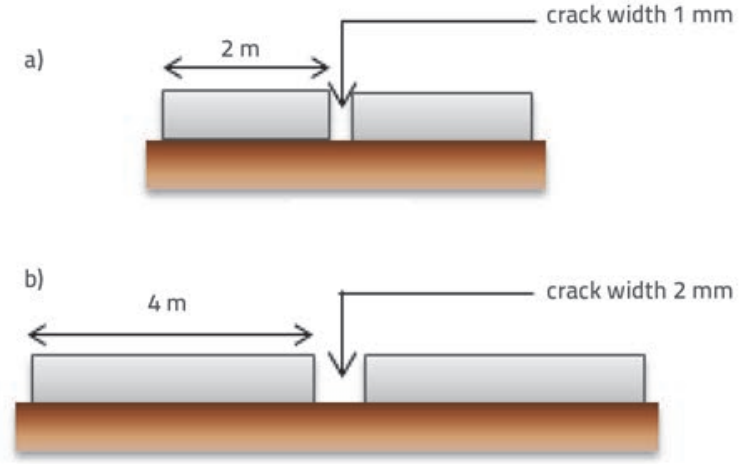

Figure 3. Effect of uncracked joints on crack width of activated joint [22]

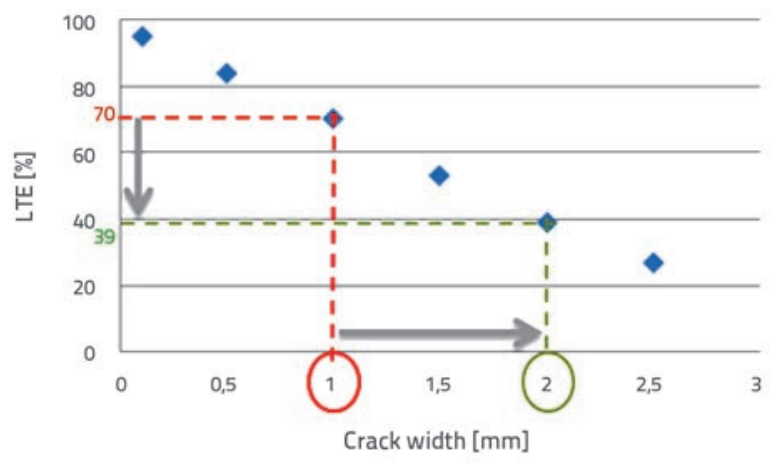

Figure 4. Variations of LTE with crack width [22]

Taking that a LTE of $60-70 \%$ is considered appropriate for an adequate in-service performance of JPCPs, it can be seen in Figure 4 how the presence of $\mathrm{UnCr}$ J reduces the LTE from appropriate provision ( $\mathrm{LTE}=70 \%$ ) to inappropriate provision (LTE $=39 \%$ ).

Regarding possible influence of traffic on joint activation, Beom \& Lee [15] and Lee \& Stoffels [16] analysed development of joint activation in traditional JPCPS geographically distributed across the USA and Canada. After more than one year in service (thus under the effects of traffic), they concluded that the joint activation in traditional JPCPs is the result of the earlyage concrete behaviour [15]. As short slabs are indeed JPCPS as well, the joint activation is also product of the early-age concrete behaviour.

However, as short JPCP slabs can be thinner than traditional JPCP slabs, the potential effect of traffic on joint activation of this innovation was (preliminarily) evaluated on a test section in the NHL of Santiago city, Chile. The characteristics of the test section are as follows: slab length $1.8 \mathrm{~m}$, slab thickness 140 $\mathrm{mm}$, maximum aggregate size $38 \mathrm{~mm}$, no dowel bars, granular base CBR $40 \%$, and concrete flexural tensile strength $5 \mathrm{MPa}$. Load repetitions of $73 \mathrm{kN}$ were applied with the FWD over an uncracked joint of the test section (Figure 5). After 400 load repetitions the joint remained uncracked.

Although these preliminary measurements have to be additionally confirmed, this result shows what has been observed in traditional JPCPs, i.e. the activation of joints at short slabs JPCPs is mainly based on the early-age concrete behaviour. In effect, even if future research shows some influence of traffic in the joint activation of this innovation, there is still no doubt that the main cause of it is the early-age concrete behaviour in the pavement. Therefore, a new approach able to model the important phenomenon of uncracked joints is required.

\section{System approach for evaluating effects of early-age concrete behaviour on structural performance of JPCPs}

Previous sections clearly show that a new approach for modelling the early-age concrete behaviour in JPCPs is necessary. This approach needs to be a systemic one, i.e. considering the JPCP as a system where the modelling of the cracking process includes interaction of the group of joints. This is made possible according to the system approach presented by Houben [4749]. In effect, it is possible to model this interaction when the pavement is treated as a system where the modelled length is actually the length required by the cracking pattern itself (a group of slabs) instead of the length of an isolated slab. In the Houben's system approach [47-49], a particular cracking pattern is developed in time and space according to specific conditions of the JPCP under analysis. In effect, the cracking 
process is not only affected by the development in time of material properties, but also by the geometry of pavement (thickness, slab length), time of JPCP construction, and the sawcutting method applied (conventional method or shallow sawcutting), etc.. Hence, this approach considers all interactions in the JPCP system for the prediction of crack width, for instance the $\mathrm{CW} 1^{\text {st }}$ in Figure 2. Furthermore, the model of Houben [4749] considers viscoelastic behaviour of concrete through an appropriate relaxation factor (Figure 6).

The factorial design with independent variables of the system approach is presented in Figure 6. Houben [47-49] uses equations from Eurocode 2 [50] (time-dependent concrete properties and deformations) and assumptions based on the engineering judgment. In Figure 6, the Relative Joint Depth (RJD) is the ratio between the saw-cut depth and the JPCP thickness. In the systemic approach, tensile stresses occurring in concrete pavement (as a product of restricted deformation) follow from Hooke's law, but are affected by viscoelastic behaviour of concrete (relaxation). In addition, the distance between primary cracks is determined by the so-called breathing length $\left(\mathrm{L}_{\mathrm{a} 1}\right)$ (Figure 7). This distance establishes the joints where the $1^{\text {st }}$ series of cracks are produced and how the cracking process will develop. Further details can be found in Houben's work [47-49].

$L_{a 1}(t)=\frac{E_{c m}(t) \cdot \varepsilon(t)}{\gamma \cdot f}$

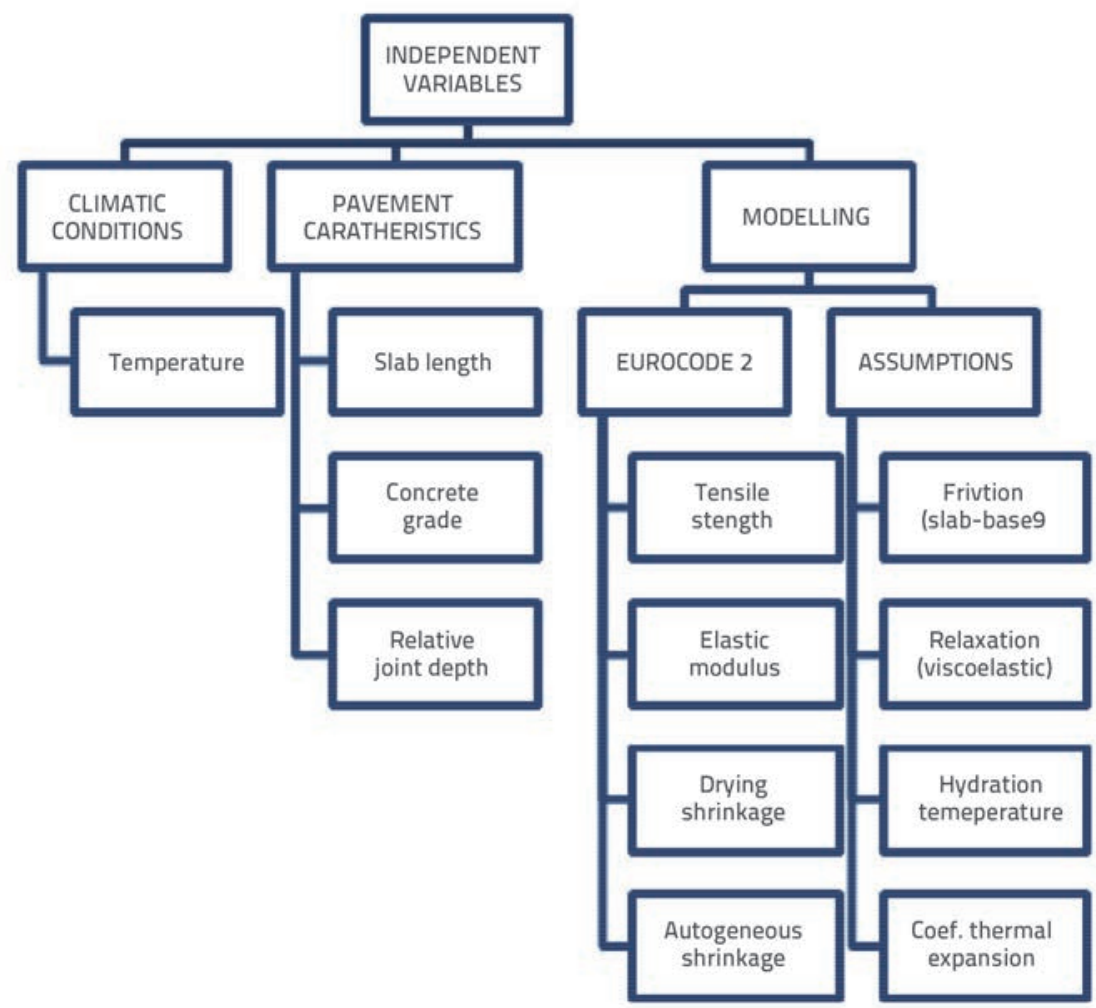

Figure 6. Factorial design with independent variables of the Houben's model
Where $E_{c m}(t)$ is modulus of elasticity (MPa) at the moment of the cracks; $\varepsilon(t)$ is maximum total obstructed deformation of pavement at the moment of the primary cracks $(-) ; \gamma$ is volume weight of concrete $\left(\mathrm{kN} / \mathrm{m}^{3}\right)$; f friction between the concrete slab and underlying base (-).

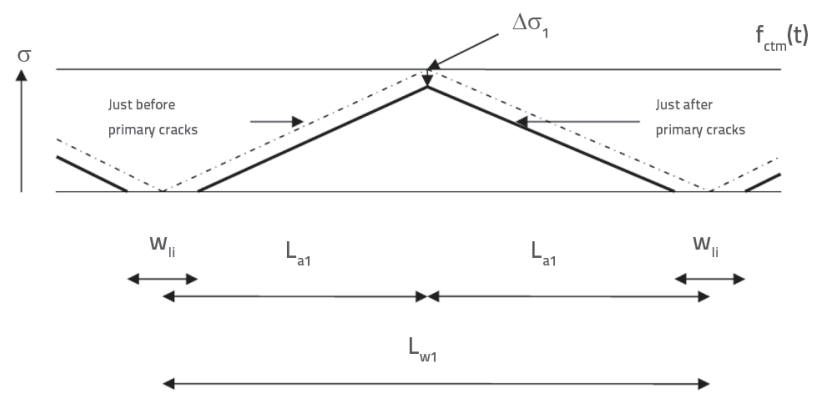

Figure 7. Tensile stresses in concrete pavement at the time of primary cracks [47-48]

Pradena and Houben [51] compared Houben's assumptions with more sophisticated models in order to find out if significant differences could be produced in relevant results to evaluate the effects of the early-age concrete behaviour on structural performance of JPCPs. With the exception of the relaxation factor, these comparisons did not produce significant changes (further details can be found in Pradena and Houben [5152]). The case of relaxation factor is special due to the lack of experimental data and models based effectively on the relaxation since early-age instead of on creep [53]. In addition, significant differences were found between the few models available (based on the relaxation itself). In this way, Pradena and Houben [52] proposed a new general equation for the relaxation factor, i.e. an equation including calibration constants to be adjusted in the scope of a calibration process. Although being in that general state (without calibration), the proposed equation has been the basis for relaxation applied by Xuan [54], Mbaraga [55] and Wu [56] in their investigations. Xuan [54] analysed the cracking process of cement-treated mix granulates with recycled concrete and masonry for use in pavement bases. Similar analysis was made by Mbaraga [55] and Wu [56], but they used it for cement stabilized bases with an additive. Furthermore, Pradena and Houben [57] made preliminary comparisons with field measurements and studied the effect of saw-cutting methods in the reduction and elimination of uncracked joints [58-59]. 
Finally, Pradena [22] calibrated the equation of relaxation with field measurements in JPCPs in Belgium and Chile. Hence, the calibrated model of Pradena and Houben [22] for the earlyage concrete behaviour allows evaluation of the effects of the early-age concrete behaviour on structural performance of JPCPs. Furthermore, Pradena [22] proposed a practical model calibration procedure useful for highway agencies, departments of transportation, municipal transportation agencies, and other institutions, as related to structural design of JPCPs (normative institutions, concrete associations, consultants, research groups, universities, etc.).

\section{Conclusion}

The presence of uncracked joints, resulting from the early-age concrete behaviour, produces an effective slab length different from the designed slab length. In addition, it produces wider cracks which certainly affect structural performance of JPCPs, especially the non-dowelled pavements. In effect, the aggregate interlock is the most influential load transfer mechanism in such pavements. And the aggregate interlock depends directly of the crack width (at joints) which is the product of the early-age concrete behaviour in pavement. Hence, relevant results of the early-age concrete behaviour must be incorporated in the structural design of JPCPs. This is particularly important for the structural design of innovative short JPCP slabs, which are parts of non-dowelled pavements, i.e. the LTE depends directly on the crack width at joints.

\section{REFERENCES}

[1] Buch, N., Frabizzio, M.A., Hiller, J.E.: Impact of coarse aggregates on transverse crack performance in jointed concrete pavements. ACI Materials Journal, 97 (2000) 3, pp. 325-332.

[2] Hanekom, A.C., Horak, E., Visser, A.T.: Comparison of South African and American aggregate interlock efficiency at concrete pavement joints. $16^{\text {th }}$ ASCE Engineering Mechanics Conference, Seattle, USA, 2003.

[3] IPRF, Joint load transfer in concrete airfield pavements: final report. (Report No. IPRF-01-G-002-05-2). Rosemont, IL: Innovative Pavement Research Foundation, 2011.

[4] Roesler, J.R., Cervantes, V.G., Amirkhanian, A.N.: Accelerated Performance Testing of Concrete Pavement with Short Slabs. International Journal of Pavement Engineering, 13 (2012) 6, pp. 494-507, https:// doi.org/10.1080/10298436.2011.575134

[5] Covarrubias, J.P.: Design of concrete slabs with optimized geometry. $2^{\text {nd }}$ International Conference on Best Practices for Concrete Pavements, Florianopolis, Brazil, 2011.

[6] Covarrubias, J.P.: Design of concrete pavement with optimized slab geometry. Revista Ingeniería de Construcción, 27 (2012) 3, pp. 181-197.
To evaluate the effects of the early-age concrete behaviour on structural performance of JPCPs it is necessary to model the cracking process in JPCPs. Nowadays, more than models to predict this process, what it is available are different formulas to calculate part of it (the joint opening). However, these formulas are not able to model the interaction (in time and space) and the effects of the behaviour of the group of slabs on prediction of a particular joint opening. This has caused significant differences between the model predictions and the joint opening values observed in real-world JPCPs. Hence, a new modelling approach is necessary in which the cracking pattern is not only dependant on the development in time of material properties, but also on the interaction of the group of joints, pavement geometry, JPCP construction time, saw-cutting method applied, and other variables. This type of approach is the one used by Pradena and Houben to predict a particular crack width or the presence of uncracked joints in JPCPs.

\section{Acknowledgements}

The following organizations and persons are acknowledged: National Highway Laboratory of Chile, the Chilean Institute of Cement and Concrete, Mr. Luc Rens (Federation of Belgian Cement Industry) and the Agency of Roads and Traffic of the Province of Limburg, Belgium.

[7] Covarrubias, J.P.: Improved concrete pavement slabs for streets, roads or highways and the methodology for the slab design. Patent Application to World Intellectual Property Organization, W02007/042338, 2007.

[8] Covarrubias, J.P.: Una Losa de Hormigón para Realizar la Pavimentación de Calles, Caminos, Carreteras y Autopistas donde el Largo, Ancho y Espesor de la Losa Están Asociados a la Distancia Libre de las Ruedas Delanteras o Traseras de un Camión de Carga Patrón Promedio, y Método de Construcción de Una Losa. Chilean Patent No. 44820, 2009a

[9] Covarrubias, J.P.: Concrete pavement slabs for streets, roads or highways and the methodology for the slab design. U.S. Patent $7,571,581 \mathrm{~B} 2,2009 \mathrm{~b}$.

[10] AASHTO, Guide for design of pavement structures. American Association of State Highway and Transportation Officials, Washington D.C., 1993.

[11] NCHRP, Guide for Mechanistic-Empirical Design of New and Rehabilitated Pavement Structures. Final Document, NCHRP Project 1-37A, Transportation Research Board, National Research Council, U.S., 2003. 
[12] Du Plessis, L., Strauss, P.J., Perrie, B.D., Rossmann, D.: Accelerated Pavement Testing of Load Transfer through Aggregate Interlock and the influence of Crack Width and Aggregate Type - a case study. International Workshop on Best Practices for Concrete Pavements, Recife, Brazil, 2007.

[13] Roesler, J.R., Wang, D.: An analytical approach to computing joint opening in concrete pavements. $6^{\text {th }}$ RILEM International Conference on Cracking in Pavements, Chicago, USA, 2008, https:// doi.org/10.1201/9780203882191.ch8

[14] Zhang, J., Li, V.: Influence of supporting base characteristics on shrinkage-induced stresses in concrete pavements. Journal of Transportation Engineering, 127 (2001) 6, pp. 455-462, https:// doi.org/10.1061/(ASCE)0733-947X(2001)127:6(455)

[15] Beom, C.J., Lee, S.W.: Effects of uncracked joints in jointed concrete pavements. KSCE Journal of Civil Engineering, 11 (2007) 3, pp. 141-144, https:// doi.org/10.1007/BF02823893

[16] Lee, S.W., Stoffels, S.: Analysis of in situ horizontal joint movements in rigid pavements. Transportation Research Record No. 1778, (2001), pp. 9-16, https:// doi.org/10.3141/1778-02

[17] Lee, S.W., Stoffels, S.: Effects of Excessive Pavement Joint Opening and Freezing on Sealants. Journal of Transportation Engineering, 129 (2003) 4, pp. 444-450, https:// doi.org/10.1061/(ASCE)0733$947 \times(2003) 129: 4(444)$

[18] Lee, S.W.: A probabilistic model for joint-movements in jointed concrete pavements. KSCE Journal of Civil Engineering, 7 (2003) 2, pp. 141-146, https:// doi.org/10.1007/BF02841972

[19] Morian, D., Suthahar, N., Stoffels, S.: Evaluation of rigid pavement joint seal movement. Transportation Research Record No. 1684 (1999), pp. 25-34, https:// doi.org/10.3141/1684-04

[20] Zollinger, D.G., Tang, T., Xin, D.: Sawcut Depth Considerations for Jointed Concrete Pavement Based on Fracture Mechanics Analysis. Transportation Research Record No. 1449, (1994), pp. 91-100.

[21] Pradena, M.A., Houben, L.J.M.: Uncracked joints in plain concrete pavements: causes, effects and possibilities of improvements. Journal of Transport Literature, 10 (2016) 1, pp. 40-44, https:// doi.org/10.1590/2238-1031.jtl.v10n1a8

[22] Pradena, M.A.: The effects of the early-age concrete behaviour on the in-service performance of jointed plain concrete pavements. PhD thesis. Delft University of Technology, the Netherlands, 2017.

[23] Morian, D., Stoffels, S.: Joint seal practices in the United States, observations and considerations. Transportation Research Record No. 1627, (1998), pp. 7-12, https:// doi.org/10.3141/1627-02

[24] Haas, R., Hudson, W.R.: Defining and serving clients for pavements. Transportation Research Record No. 1524, (1996), pp. 1-9, https:// doi.org/10.3141/1524-01

[25] Ioannides, A.M.: Analysis of slabs-on-grade for a variety of loading and support conditions. PhD Thesis, University of Illinois, UrbanaChampaign, 1984

[26] Ioannides, A.M.: Extension of Westergaard solutions using dimensional analysis. $2^{\text {nd }}$ International Workshop on the Design and Evaluation of Concrete Pavements, Siquenza, Spain, 1990

[27] Ioannides, A.M.: Concrete pavement analysis: the first eighty years. International Journal of Pavement Engineering, 7 (2006) 4, pp. 233-249, https:// doi.org/10.1080/10298430600798481

[28] Ioannides, A.M., Salsilli, R.A.: Temperature curling in rigid pavements: an application of dimensional analysis. Transportation Research Record No. 1227, (1998), pp. 1-11.
[29] Salsilli, R.: Calibrated mechanistic design procedure for jointed plain concrete pavements. PhD Thesis. University of Illinois, Urbana-Champaign, 1991.

[30] Salsilli, R.: Design manual for industrial floors (in Spanish). Chilean Institute of the Cement and Concrete, Santiago, Chile, 2015.

[31] Raad, L., Marhamo, L.K.: Evaluation of two-layer pavements using dimensional analysis. Transportation Research Record No. 1307, (1991), pp. 99-110

[32] Khazanovich, L., Yu, T.H., Darter, M.I.: Prediction of critical JPCP stresses in the mechanistic-empirical 2002 design guide. $9^{\text {th }}$ International Symposium on Concrete Roads, Istanbul, Turkey, 2004

[33] Bordelon, A., Roesler, J., Hiller, J.: Mechanistic-Empirical Design Concepts for Jointed Plain Concrete Pavements in Illinois. (Research Report ICT-09-052). Springfield, IL: Illinois Department of Transportation, 2009.

[34] Salsilli, R., Wahr, C., Delgadillo, R., Huerta, J., Sepúlveda, P.: Field performance of concrete pavements with short slabs and design procedure calibrated for Chilean conditions. International Journal of Pavement Engineering, 16 (2015) 4, pp. 363-379, https:// doi. org/10.1080/10298436.2014.943129

[35] Ioannides, A.M., Thompson, M.R., Barenberg, E.J.: Westergaard solutions reconsidered. Transportation Research Record No. 1043, (1985), pp. 13-23.

[36] Ioannides, A.M., Korovesis, G.: Aggregate interlock: a pure-shear load transfer mechanism. Transportation Research Record No. 1286, (1990), pp. 14-24

[37] Ioannides, A.M., Alexander, D., Hammons, M., Davids, C.: Application of artificial neural networks to concrete pavement joint evaluation. Transportation Research Record No. 1540, (1996), pp. 56-64, https:// doi.org/10.3141/1540-08

[38] Cabrera, C.: Calibration of the cracking model of plain concrete pavements implemented in the system GIMPh (in Spanish). Civil Engineering Degree Thesis. Universidad de Chile, Santiago, 1998

[39] Houben, L.J.M.: Structural design of pavements, part IV: Design of concrete pavements. Lecture notes CT4860, Delft University of Technology, the Netherlands, 2006.

[40] Söderqvist, J.: Design of concrete pavements: design criteria for plain and lean concrete. Bachelor Thesis, KTH Royal Institute of Technology, Stockholm, 2006

[41] Hiller, J.E.: Development of mechanistic-empirical principles for jointed plain concrete pavement fatigue design. PhD Thesis, University of Illinois, Urbana-Champaign, 2007.

[42] Chilean Highway Agency, Complement to the Technical Specifications of the Highway Manual, Annex 1: Design Method to Thin Cement Concrete Pavement (in Spanish). Ministry of Publics Works, Santiago, Chile, 2012.

[43] Salsilli, R., Wahr, C., Delgadillo, R., Huerta, J., Sepúlveda, P.: Design Method for Concrete Pavements with Short Slabs Based on Westergaard's Equations and Dimensional Analysis. 92 ${ }^{\text {nd }}$ Transportation Research Board Annual Meeting, Washington DC, USA, 2013

[44] Salsilli, R., Wahr, C.: Trends in Concrete Pavements (in Spanish). Seminar New Challenges and Trends in Concrete Pavements, Chile, 2010.

[45] Salgado, M.: Analysis and Prediction of the Behaviour of SemiRigid Short Slabs Concrete Pavements (in Spanish). International Seminar Latest Advances in Design and Construction of Concrete Pavements, Buenos Aires, Argentina, 2011. 
[46] Davids, W.G., Mahoney, J.P.: Experimental Verification of Rigid Pavement Joint Load Transfer Modeling with EverFE. Transportation Research Record No. 1684, (1990), pp. 81-89, https:// doi.org/10.3141/1684-10

[47] Houben, L.J.M.: Model for transversal cracking in non-jointed plain concrete pavements as a function of the temperature variations and the time of construction. Report 7-08-216-6, Road and Railway Engineering, Delft University of Technology, 2008.

[48] Houben, L.J.M.: Model for transversal cracking (at joints) in plain concrete pavements. Report 7-08-216-5, Road and Railway Engineering, Delft University of Technology, 2008.

[49] Houben, L.J.M.: Transversal cracking in jointed plain concrete pavements for Dutch climatic conditions. Report 7-08-216-7, Road and Railway Engineering, Delft University of Technology, 2008.

[50] EN 1992-1-1, Design and Calculation of concrete structures Part 1-1: General rules and rules for buildings. Brussels: Europe Committee for Standardization, 2005.

[51] Pradena, M.A., Houben, L.J.M.: Causes and effects of longitudinal shrinkage and temperature stresses on JPCP for Dutch conditions. $10^{\text {th }}$ International Conference on Concrete Pavements, Quebec, Canada, 2012.

[52] Pradena, M.A., Houben, L.J.M.: Analysis of the Stress Relaxation in Plain Concrete Pavements. Baltic Journal of Road and Bridge Engineering, 10 (2015) 1, pp. 46-53, https:// doi.org/10.3846/ bjrbe.2015.06
[53] Atrushi, D.: Tensile and Compressive Creep of Early Age Concrete: Testing and Modelling. Doctoral Thesis, The Norwegian University of Science and Technology, Trondheim, 2003.

[54] Xuan, D.: Cement treated recycled crushed concrete and masonry aggregates for pavements, Doctoral Thesis, Delft University of Technology, Delft, 2012.

[55] Mbaraga, A.N.: Shrinkage characterisation, behavioural properties and durability of cement-stabilized pavement materials. Doctoral Thesis, Stellenbosch University, Stellenbosch, 2015.

[56] Wu, P.: Cement stabilized materials with use of RoadCem additive, Doctoral Thesis, Delft University of Technology, Delft, 2015

[57] Pradena, M.A., Houben, L.J.M.: Sustainable Pavements: An Analysis of the Crack Width in Jointed Plain Concrete Pavements with Short Slabs. In Proceedings of the $14^{\text {th }}$ International Multidisciplinary Scientific GeoConference SGEM, 2014.

[58] Pradena, M.A., Houben, L.J.M.: Innovations in Concrete Pavements for a Sustainable Infrastructure. Proceedings of the $2^{\text {nd }}$ International Conference on Traffic and Transport Engineering, Belgrade, Serbia, 2014

[59] Pradena, M.A., Houben, L.J.M.: Sustainable Pavements: Influence of the Saw-Cutting Method on the Performance of JPCP. Proceedings of the $14^{\text {th }}$ International Multidisciplinary Scientific GeoConference, Varna, Bulgaria, 2014, https:// doi.org/10.5593/ SGEM2014/B62/S26.043 